\title{
SOME TECHNIQUES OF TAXATION IN THE UNITED KINGDOM
}

Topay, when the tax structure of the United States is in violent flux, the tax system employed in the United Kingdom ${ }^{1}$ offers a valuable source of information and experience. The effectiveness of the British technique of determining taxable income, with particular reference to the treatment of capital gains and losses, has long been a controversial issue in this country. And the various wartime measures employed in Great Britain to raise revenue, reduce the possibilities of inflation and meet the difficulties of tax collection suggest possible solutions to our more immediate tax problems.

\section{The Schedular System}

In the United Kingdom income is classified as to source and tax is computed in accordance with a schedular system. To be taxable, income must fall within at least one of five Schedules, A, B, C, D, or E. ${ }^{2}$ Under Schedule $A$, the taxpayer is assessed on all income arising from land "capable of actual occupation." 3 The admeasurement of assessment is the "annual value" of the property, which is a hypothetical sum ${ }^{4}$ determined every five years and based on the rent at which the property is or could be leased by the year. Normally the tax is charged against the occupant of the property, the person having the use of the lands or tenements. ${ }^{6}$ Schedule B applies to income derived from the occupation of agricultural lands, woodlands, deer forests, and other similar classes of property taxed under Schedule $A .^{7}$ In most cases the assessment is made by a rule-of-thumb method ${ }^{8}$ on three times the annual value of the property. ${ }^{\circ}$ Although many sources of income taxable under $A$ are not included in $B$, all sources under $B$ are included in $\Lambda$. Thus whenever Schedule B applies, the tax levied is in addition to that levied under Sched-

1. The British tax system is today a product of many overlapping acts, each amending and modifying the 1918 Income Tax Act, which consolidated all the earlier legislation. Income Tax Act, 1918, 8 \& 9 Gro. V, c. 40 (1918). See 1 Rep. Incone TAx Codirication Committee (1936). See aiso Bernard, Income Tax in Great Britain (1928); Konstant, The Law of Income Tax (8th ed. 1940) 587-805; Maglll, Parker and King, A Summary of the British Tax System (1934); Spaulding, The Income Tax in Great Britain and the United States (1927).

2. See Income Tax Act, 1918, 8 \& 9 Geo. V, c. 40, First Sched.

3. Id., First Sched., Sched. A, No. I. See Konstan, op. cit. supra note 1, at 32-34.

4. See The King v. Special Commissioners of Income Tax c.x parte Essex Hall, [1911] 2 K. B. 434, 441, 444.

5. Finance Act, $1930,20 \& 21$ Geo. V, c. $28, \S 27$ (1).

6. See Hill v. Gregory, [1912] 2 K. B. 61.

7. Income Tax Act, 1918, 8 \& 9 Geo. V, c. 40, First Sched., Sched. B. Sec KonSTAM, op. cit. supra note 1 , at 63-64.

8. See MAGILL, PARKER AND KING, op. cit. supra note 1 , at 18.

9. Finance Act, 1942, 5 \& 6 GEO. VI, c. $21, \S 28(2)$. 
ule A. ${ }^{10}$ Schedule $C$ embraces "all profits arising from interest, public annuities, dividends and shares of annuities payable in the United Kingdom out of any public revenue in the United Kingdom or elsewhere, in any year of assessment." ${ }^{13}$ Schedule D is subdivided into six Cases, the first five of which include profits from trades, businesses, and professions, interest and profits of uncertain value, and dividends from foreign securities and possessions. 12 Case VI, known as the "sweeping up" clause, covers "any annual profits or gains not falling under any of the foregoing Cases, and not charged by virtue of any other Schedule." 13 Under Schedule E, the taxpayer is assessed on income arising from any offices or employment. ${ }^{14}$ Assessments under Schedules $C, D$, or $E$, unlike those under $A$ and $B$, are hased on actual income received rather than on fictional sums.

Whether income is taxable under one Schedule or another is a question of fact ${ }^{15}$ which in some instances is extremely difficult to determine, particularly when Schedules $A, B$, or D are involved. ${ }^{10}$ It was once supposed that there were as many types of income tax as Schedules. But in 1901, the House of Lords clearly stated that the income tax "is one tax, not a collection of taxes

10. See Konstanr, op. cit. supra note 1 , at 64 .

11. Income Tax Act, 1918, \& \& 9 GEo. V, c. 40, First Sched., Sched. C, Rule 1(a).

12. Except those chargeable under First Schedule, Schedule C. Income Tax Act, 1918, S \& 9 GEo. V, c. 40, First Sched, Sched. D(2).

13. Ibid.

14. Id., First Sched., Sched. E.

15. See Mialcolm v. Lockhart, [1919] A. C. 463; cf. Marsizall v. Tweedy, [1927] Sess. Cas. 243; Earl of Derby v. Bassom, 42 T. L. R. 380 (K. B. 1926) ; Earl of Derby v. Aylmer, [1915] 3 K. B. 374.

16. For example, profits from mines, quarries, iron and waterworks formerly tazed under Schedule A, are now assessed under Schedule D. Finance Act, 1926, 16 \& 17 Gro. V, c. 22, \$28. Moreover, it was once held that the Crown could tax a particular subject under whichever of the Cases of Schedule D resulted in the greatest liability. Sce Liverpool \& Iondon \& Globe Insurance Co. v. Bennett, [1913] A. C. 610. See also Rosyth Building \& Estate Co. v. Rogers, [1921] Sess. Cas. 372, in which it was held that the Crown could choose between the various Schedules and assess a landowning company either under Schedule $A$ on the aggregate of the annual values of its properties or under Schedule $D$ on the balance of its trading profits. Although the House of Lords rejected this theory in Fry v. Salisbury House Estate, [1930] A. C. 432, as inconsistent with the scheme of the income tax acts, the legislature later provided that any excess rent not charged under Schedule A could be assessed under the "sweeping up" clause of Schedule D. Finance Act, $1940,3 \& 4$ GEo. VI, c. $29, \S \S 13-15$. The courts also attempted to apply a notion of the mutual exclusiveness of the Schedules to assessments under Schedule B by holding that once it was found that profits arose from the occupation of land, assessment upon the annual value under that Schedule exhausted all of the profits and Schedule $D$ could not be applied to charge any excess of actual profit over annual value. See Bacl: v. Daniels, [1925] 1 K. B. 526; Lord Glanely v. Wightman, 49 T. L. R. 356 (H. L. 1933). But by provisions of the Finance Act of 1941, farming and marliet gardening are treated as a business, and profits arising therefrom are now assessed under Case I of Schedule D. Finance Act, 1941, 4 \& 5 GEo. VI, c. 30, $\$ 10(1)$; Finance Act, 1942, 5 \& 6 GEO. VI, C. $21, \$ 28(6)$. 
essentially distinct." 17 In accordance with this view of the tax, the tendency has been to modify the schedular scheme whenever it interferes with the receipt of revenue or notions of equity. Thus income usually taxed under onc Schedule is in some circumstances taxed under another. The schedular system is, therefore, a formal rather than a substantive characteristic of the British income tax system. ${ }^{18}$ A superficial examination of the formal system enployed in Great Britain for determining taxable income does indicate a wicle disparity between the bases of taxation there and in the United States. Yet the divergence is not, in essence, so pronounced, there being a substantial concurrence in the concept of income employed in the two countries. But since fewer and more realistic classifications are involved, the United States method of arriving at taxable income would appear to be more efficient than that utilized in Great Britain.

\section{Taxation of Capital Gains}

A perhaps more significant differentiation between income concepts in the United States and the United Kingdom arises in the treatment of capital gains transactions. While all capital gains are taxed in the United States, the tax liability resulting from these transactions is limited uncler the British system. The limitation apparently results, in some measure, from the interplay of the basic inefficiency of the schedular system and social policy.

In order to tax capital gains it has been necessary to include them in Schedule $D$, for the terms of $C$ and $E$ and the basis of assessment under $\Lambda$ and $B$ exclude any possibility of their being brotght within the scope of those Schedules. Moreover, Schedule D is a residual Schedule designed to catch, in the Cases into which it is subdivided, profits which would not otherwise be taxed. ${ }^{19}$ By virtue of another process of exclusion within Schedule D, capital gains have had to be taxed under either Case I or Case VI. Under Case I taxes are charged "in respect of any trade" " 0 and trade is saicl to include "every trade, manufacture, adventure or concern in the nature of tracle." 21 But the language of this Case has never been followed literally. If it were, a capital gain, in order to fall within its purview, would have to be derived from a transaction in the nature of a trade. And it is this literal construction of Case I which has led to the popular belief that capital gains are not taxed in the British system unless the taxpayer is a trader in capital assets. Case VI, on the other hand, embraces "annual profits or gains not falling under any of the [other] Cases and not charged by virtue of any other Schedule." 22 Despite the sweeping nature of its wording, the courts have attempted to limit the scope

17. London County Councib v. Attorney-General, [1901] A. C. 26, 35.

18. See Magild, Parker and King, op. cit. supra note 1 , at $17,19$.

19. See Fry v. Salisbury House Estate, [1930] A. C. 432, 454.

20. Income Tax Act, 1918, 8 \& 9 Geo. V, c. 40, Sched. D, Case I.

21. Id., §237.

22. Id., Sched. D, Case VI. 
of this Case through diverse interpretations of the word "annual." The phrase "annual profits" was once said to mean profits recurring year by year," derived from a source capable of or intended to be capalsle of producing profits year by year. ${ }^{24}$ Under this interpretation, casual profits derived from transactions within a single year were excluded from Case VI, since they did not recur annually.

The courts, however, were then faced with the anomaly wherehy a trafer could escape taxation on profits from transactions within a single year containing all the essential features of a trade merely hecause the profits were not recurring. It was, therefore, finally decided that the phrase "annual prufits" refers to profits realized within the year of assessment.". This conclusion was based on the fact that the word "annual" was first used in the . lets of $1842^{23}$ and 1853,27 which, unlike the $1918 \mathrm{Act},{ }^{28}$ were designed to cover short periods of time and applied only to profits falling within the particular year of their operation. Although the 1918 Act clanged the 1842 Act's phraseology in Rule II, Case VI from "profits or gains received annually" 29 to "profits or gains arising in the year of assessment," 30 the context in which the term "annual" was used in the 1918 Act suggested that it referred to gains accruing within the year of assessment. With this new definition of "annual" little authority remained for restricting assessments under Case $\mathrm{VI}$, and all capital gains transactions could be taxed.

There was, nevertheless, some doctrine of a general nature which restricted the scope of this Case by excluding from it "anything in the nature of a capital accretion," and a casual profit made on an isolated purchase and sale unless merged with similar transactions in the carrying on of a trade. ${ }^{31}$ These restrie-

23. See discussion of this contention in Ryall v. Honeywill, [1923] 2 K. B. 447, 454-55.

24. It might be argued that the terminology of the 1918 Income Tax Act supports this view. See consideration and rejection of this argument in Martin v. Lowry, [1926] $1 \mathrm{~K}$. B. 550,560 . Yet support for this view may be found in an early decision concerning the power given by Section 40 of the Income Tax Act, 1853, 16 \& 17 VIcT., c. 34, to deduct the amount of income tax from the payment of any yearly interest of money, which held that that section did not authorize the deduction frum payment of interest of a loan from a banker to a customer for a period of less than a year. See Goslings \& Sharpe v. Blake, 23 Q. B. D. 324 (18s9). Cf. Income Tax Act, 1918, \& \& 9 Gro. V, c. 40, Gen. Rules 19(1).

25. See Martin v. Lowry, [1926] 1 K. B. 550, 564. See also Ryall v. Hoare, [1923] 2 K. B. 447.

26. Income Tax Act, $1842,5 \& 6$ VIcT., c. 35.

27. Income Tax Act, 1853, 16 \& 17 Vicr., c. 34.

23. Income Tax Act, 1918, S \& 9 Geo. V, c. 40.

29. Income Tax Act, 1842, $5 \& 6$ Vrcr., c. 35.

30. Income Tax Act, 1918, S \& 9 Geo. V, c. 40, First Sched, Sehcd. D, Case VI, Rule 2.

31. Rowlatt, J., in Ryall v. Honeywill, [1923] 2 K B. 447, 454. See also Lord Sands in Commissioners of Inland Revenue v. Livingston, [1927] Sess. Cas. 251, 256: "According to understanding, practice and, I think, authurity, ever since the Incume Tax was introduced, it has been recognised that the profit of an isolated transaction by way of 
tions were first enunciated formally by Lord Dunedin ${ }^{32}$ who, by a backhanded process of reasoning, ascribed to the term annual some of the characteristics of the above principles. Under his ruling "annual" is not limited to receipts recurring every year, but a receipt to be taxable must be "something in the nature of income." 33 Although income does not include "pure" capital gains or casual profits, it does include such gains if they can be said to have arisen from "an adventure in the nature of trade" ${ }^{34}$ or to be receipts in "the nature of revenue or income." Thus the income tax base has been contracted by excluding "gains of a capital nature" and then expanded by including gains which are derived from transactions in the nature of trade or are receipts in the nature of income. The criteria established in this manner are obviously flexible and can be made to yield to considerations of policy.

In the conceptual development of these criteria a distinction has been made between income arising from individual and from recurring transactions. When "the nature of trade" concept is employed, essentially the samc kind of rationale is involved in both types of transactions. As might be assumed, however, income from recurring transactions is more apt to be considered as arising from an adventure in the nature of trade than income derived from individual transactions. It would appear that all profits derived from transactions regularly incidental to the line of business in which they occur are considered as arising from an adventure in the nature of trade. ${ }^{35}$ Income from individual and recurring transactions is again accorded substantially similar treatment when profits are placed in the "nature of revente or income" category. ${ }^{30}$ Yet the inclusion of profits within the nature of revenue or income category, when the nature of trade concept is inapplicable, is more clearly demonstrated in the multiple transaction cases. ${ }^{37}$

purchase and resale at a profit, not within the ambit or trade of the party making the profit, is not assessable to Income $T a x$, 'as profits or gains arriving or accruing to any person residing in the United Kingdom from any trade." See also Earl Haig's Trustees v. Commissioners of Inland Revenue, [1939] Sess. Cas. 676, 683. The opinion of the Lord President indicates that he was still willing on general principles to exclude capital accretions from the category of profits or gains. For earlier decisions, see: McKinlay v. Jenkins, 10 Tax Cas. 372, 403 at 404 (K. B. 1926) ; J. \& M. Craig v. Cowperthwaite, [1914] Sess. Cas. 338.

32. See Jones v. Leeming, [1930] A. C. 415, 422.

33. Id. at 423. Applied in Ear1 Haig's Trustees v. Commissioners of Inland Reventuc, [1939] Sess. Cas. 676, 683, 687.

34. For the general development of the meaning of "trade" see KonsTAM, op. cit. supra note 1, at 80-84. For further dissertations on the meaning of trade see: Commissioners of Inland Revenue v. Newcastle Breweries, 95 L. J. K. B. 936, 941 (C. A. 1926); Port of London Authority v. Commissioners of Inland Revenue, [1919] 2 K. 13. 608, 613. 14 ; Muat v. Stewart, 27 Sc. L. R. 294, 297 (Ex. Scot. 1890).

35. See Commissioners of Inland Revenue v. Livingston, [1927] Sess. Cas. 251.

36. See Townsend v. Grundy, 18 Tax Cas. 140 (K. B. 1933) ; Cooper v. Stubbs, [1925] 2 K. B. 753.

37. See Cooper v. Stubbs, [1925] 2 K. B. 753, 767-74. Although there seems to have been an attempt to restrict this principle to transactions in which there has been no original investment of money, on the doctrinal ground that when there is "no investment of 
The principles involved in ascertaining taxable income under the "nature of trade" concept ${ }^{38}$ are illustrated by two cases concerning profits from the exchange of foreign currency. In one case, a corporation, in order to execute a contract the following autumn, purchased lira in March which it would have ordinarily purchased in the fall. The currency increased in value, and the corporation sold it in May. But the profits from the sale were not taxed.30 In the other case, a commission agent selling imported goods made advances to his principal. Later these advances were repaid in accordance with the regular procedure in this type of transaction. In the interim the value of the dollar had increased, and the profit made by the agent from this apprecintion was taxed. ${ }^{40}$ In both cases, there was a capital transaction in the theoretical sense of the term, and a resulting capital profit. Neither taxpayer was a dealer in capital assets. Yet one was taxed and the other was not. The transactions from which the profits arose can, however, be distinguished. The transaction in the first case was not a part of the regular business practice, for the purchase of the lira in March was a matter of whim or accident, and the consequent profit was unexpected and fortuitous. On the other hand, the transaction in the second case was a regular and essential part of the profit-mahing enterprise. ${ }^{41}$

capital" there can be no resulting "capital accretion," this limitation has not been fnllowed. See (1937) 183 L. T. 375, 376.

38. One of the clearest situations permitting the tax is demonstrated in Californian Copper Syndicate v. Harris, 5 Tax Cas. 159 (Ex. Scot. 1904), in which a mining syndicate was formed with the express purpose of acquiring copper bearing land, developing it to some extent, and selling it at a profit. A more difficult situation is presented by a case in which profits were made from the sale of a stock of linen acquired in a single transaction by a wholesale agricultural machinery merchant, who neither before or after had any other connection with the linen trade. Martin v. Lowry, [1927] A. C. 312. In upholding the tax, the court was influenced by the practical aspects of the transaction, such as the size of the asset, the large overhead incurred and the fact that the goods were sold to the public generally. Similarly, the profits from a single purchase and sale of one million rolls of toilet tissue were considered assessable: "The nature and quantity of the subject dealt with exclude the suggestion that it could have been disposed of otherwise than as a trade transaction. Neither the purchaser, nor any purchaser from him, was likely to require such a quantity for his own private use" Rutledge v. Commissioners of Inland Revenue, [1929] Sess. Cas. 379, 383. See also Stevens v. Hudson's Bay Co., 101 L. T. R. 96 (C. A. 1909); cf. Alabama Coal, Iron, Land \& Colonization Co. v. Mylam, 11 Tax Cas. 232 (K. B. 1926); Hudson's Bay Co. v. Thew, [1919] 2 K. B. 632. Theoretically, profits derived from the sale of patents are not taxable. Nevertheless a corporation which, among other activities, was engaged in buying patents and malkins a profit by selling them was charged with tax on profits arising from these transactions. Ducker v. Rees Roturbo Development Syndicate, [192S] A. C. 132; cf. Mills v. Jones, 46 T. L. R. 118 (H. L. 1929) ; Brandwood v. Banker, 14 Tax Cas. 44 (K. B. I923); Constantinesco v. The King, 43 T. L. R. 727 (H. L. 1927); Collins v. Firth-Brearley Stainless Steel Syndicate, 9 Tax Cas. 520 (C. A. 1925).

39. MIcKinlay v. Jenkins, 10 Tax Cas. 372 (K. B. 1926).

40. Landes Brothers v. Simpson, 19 Tax Cas. 62 (K. B. 1934).

41. Compare Ward v. Anglo-American Oil Co., 19 Tax Cas. 94 (K. B. 1934); Magraw v. Lewis, 18 Tax Cas. 222 (K. B. 1933); Bennet v. Underground Electric Rail- 
The use of the broader category, "in the nature of revenue or income," is illustrated by cases in which a tax is levied on the profits from speculative dealings in commodity futures. For example, profits from numerous spectlative transactions in cotton futures, which were entered into with no intention of taking future delivery or using the future contracts as hedges for actual transactions, were taxed as receipts "in the nature of revenue or income." 42 The regularity of a profit expectancy and profit motive was again relevant.

Those who have advocated that the United States adopt the British scheme, have maintained that it would stabilize our tax economy, by making it morc independent of profits and losses ${ }^{43}$ due to temporary price and exchange fluctuations. ${ }^{44}$ But the inconsistencies and vagaries in the British treatment of capital gains indicate that the acloption of that system could not stabilize our tax economy.

\section{The With holding Sxstem}

Once taxable income has been determined by reference to the schedular system and the difficulties in assessing "capital gains" transactions resolved, difficulty arises in the collection of the resulting tax liability. The outstanding characteristic of the British collection pattern is the substantial use of the withholding or deducting at source device. It has been estimated that 70 per cent of the British income tax is collected in this manner.45 And the broad

ways Co. of London, [1923] 2 K. B. 535. These three cases indicate that under similar circumstances the courts are less willing to allow deductions, even though the excluange loss is part of a regular business procedure, than they are to refrain from assessing profits of the exchange to income tax.

42. Townsend v. Grundy, 18 Tax Cas. 140 (K. B. 1933). It might be argucd that profits from stockmarket transactions should similarly be taxed in Great Britain. Other instances in which this principle has been invoked are demonstrated in Benson v. Counsel, [1942] 1 K. B. 364; Hobbs v. Hussey, [1942] 1 K. B. 491. See Farnsworth, Capilal or Income? (1942) 5 MoD. L. REv. 263.

43. Considerations involved in capital losses are identical with those in capital gains. See Farnsworth, Fixed or Floating Capital (1941) 4 MOD. L. REv. 310.

44. ". . . It has always been realized in England that incidental profits and losses, such as from stock speculations, should not be taxable . . unless it is the individual's profession or business. . . " "By this method the income of the government is not stubject to huge fluctuations, and collections are derived from actual income in the literal sense." N. Y. Times, March 10, 1933, p. 14, col. 6.

45. See Magill, Parker and KING, op. cit. supra note 1, at 19. Tax is withlield at the source in the landlord-tenant relationship. Income Tax Act, 1918, 8 \& 9 GEo. V, c. 40, First Sched., Sched. A, No. VIII, Rule 1, read with Finance Act, 1940, $3 \& 4$ Gto. VI, c. $29, \S 17(1)(2)$. See Drughorn v. Moore, [1924] A. C. 53; Northumberlaut (Duke) v. Commissioners of Inland Revenue [1920], A. C. 825; Benufort (Duke) v. Commissioners of Inland Revenue, Commissioners of Inland Revenue v. Anglescy (Marquess), [1913] 3 K. B. 48.

Income tax on annuities and interest is similarly collected. Reduction is allowed when the yearly interest is paid out of profits under the scope of Case III, Schedule D. Income Tax Act, 1918, supra at Gen. Rules Applicable to Scheds. A, B, C, D and E 
use to which withholding is put is apparently justified; for the government benefits by certainty of collection, and the taxpayer's burden is eased by eliminating the need to budget for the payment of this automatic delit.

Because the withholding system has been traditionally employed in the taxation of dividends, there is a profound difference in the taxation of corpurate income in Great Britain and the United States. In Great Britain corpurate dividends are never directly taxed to the individual receiving them. ${ }^{\text {to }}$ But the tax levied on the corporation at the flat, standard rate ${ }^{47}$ is in reality a tax on the shareholder collected at the source, since the corporation is entitled to deduct this tax from the dividends it pays.

This deduction was introduced into the British tax system by the Income Tax Act of 1842.48 At that time joint stock companies were in their infancy and were looked upon as large partnerships.90 Consequently the courts held that a corporation paid taxes "as agent for its shareholders." "n . Mlthough later decisions abandoned the partnership-agency rationale and concluded

$\$ \$ 19,21(1),(2)$; cf. Purdie v. Kex, [1914] 3 K. B. 112, and remarks in Marion Brooke v. Commissioners of Inland Revenue, [1917] 1 K. B. 61, 70. Any agreement for payment in full without allowing such deduction is void. Income Tax Act, 1918, suspra at Gen. Rule 23(2). An annuity comes under the same rules as yearly interest, when paid out of taxable profits. And this is so even though the payer has not in fact paid tax on those profits. But he must account for the amount deducted to the Crown even when the annuity is not paid out of taxable income. Income Tax Act, 1918, stifra at General Rule $21(1)$, (2). There is an exception relating to registered societies. Finance Act, 1933, 23 \& 24 GEo. V, c. 19, \$32(1). It may be said broadly that insofar as a so-ealled "annuity" represents the payment of capital by installments it is not within the purview of the income tax, either for purposes of direct assessment or deduction at the sururce. Sce Oswald v. Magistrates of Kirkcaldy, [1919] Sess. Cas. 147. See also Mlustoe, Duction of Incone Tax (1942) 92 L. J. 4.

Interest on public securities is deducted by the authority or agent by whom it is paid. Income Tax Act, 1918, sipra at First Sched., Sched. C. And this method of collection was finally applied to some of the tax charged on offices and employments under Schedule E.

46. See Konstanx, op. cit. supra note 1 , at 282.

47. A flat rate of 50\%. Finance Act, 1942, $5 \& 6$ Gro. VI, c. 21, \$21(1). Although the first $£ 165$ of a person's income is taxed at only $32 \% 2 \%$, Finance Act, 1927, 17 \& 18 GEo. V, c. 10, $\$ 40(2)$ as amended by Finance Act No. 2, 1940, 3 \& 4 GEo. VI, c. 48, $\$ 8(1)$, no provision is made for this discrepancy in the application of the withholding rate. Nevertheless any overpayments of tax resulting from the flat levy of $50 \%$ is eredited against the taxpayer's other tax liability, or, if none exists, is subject to refund. Sce Income Tax Act, 1918, \&\& 9 Geo. V, c. 40, \$\$16, 29.

48. Income Tax Act, 1842, 5 \& 6 VIcr., c. 35, \$54; Income Tax Act, 1918, 8 \& 9 GEo. V, c. 40, Gen. Rule 20.

49. See Attorney-General v. Ashton Gas Co., 2 Ch. 621 (1904), aff'd, [1906] A. C. 10; Gilbertson v. Fergusson, 7 Q. B. D. 562 (1881).

50. See note 49 supra. Even today the analogy between a corporation and a partnership is sometimes made. See Bradbury v. English Sewing Cotton Co., [1923] A. C. $744,769-70$. 
that the corporation and individual were completely separate taxpaying units, the notion that the tax is deducted in behalf of the individual has been retained. Yet the fact that the corporation is a separate taxpaying individual, with a mere right to deduct against the dividends it pays, indicates a departure from the pure withholding principle. Thus whether a British corporation's profits have or have not been distributed in the form of dividends is entirely immaterial in determining the liability of the corporation for tax. ${ }^{\text {22 }}$ Although the company deducts a tax on behalf of the shareholder when it pays a dividend, it cloes not pay the tax on his behalf when it pays its own tax to the Crown.

There is, therefore, no necessary correlation between the amount of tax deducted from the dividend and the amount of tax paid by the corporation. This distinction between the amount deducted and the tax paid becomes clear when the standard rate is changed from year to year. A corporation might be taxed over a series of years at very high standard rates, and if it made no distribution, it would be entitled to no deduction at these rates. When a distribution was made, the standard rate might have been lowered. The corporation would, however, be entitled to deduct only at the rate in force in the year of distribution ${ }^{53}$ and so it would, in effect, be subjected to a non-recoverable tax. On the other hand, the annual income of a corporation over a period of years might, in an extreme case, be too small to be taxable. If after this period a bulk distribution were made so that the sum of the dividends paid equaled an amount subject to taxation, the corporation could deduct tax in spite of the fact that it had actually paid none whatsoever. ${ }^{54}$

51. See Ritson v. Phillips, 131 L. T. R. 384 (K. B. 1924); Sheldrick v. South African Breweries, [1923] 1 K. B. 173; Bradbury v. English Sewing Cotton Co., [1922] 2 K. B. 569, 589; Commissioners of Inland Revenue v. John Blott, [1921] 2 A. C. 171.

Tax is assessed on a "body of persons." Income Tax Act, 1918, 8 \& 9 Gzo. V, c. 40, Gen. Rule 20. And "body of persons" is defined to mean "any body politic, corporate, or collegiate, and any company, fraternity, fellowship and society of persons, whether corporate or not corporate." Id., \$237. The corporation is assessed through any officer acting as its secretary, who may retain sufficient funds to pay the tax out of any money coming into his hands on behalf of the body. Id., $\S 106$. He is liable to make all the returns and to do all acts required for the assessment of the corporation. Id., $\S \S 106,207$, and Fifth Sched.

52. See note 51 supra.

53. Income Tax Act, 1918, 8 \& 9 Gzo. V, c. 40, Gen. Rule 20; Finance Act, 1927, $17 \& 18$ GEo. V, c. $10, \S 39(1)$; Finance Act No. $1,1931,21$ \& 22 Geo. V, c. $28, \$ 7(1)$. $A$ corporation is bound under penalty to show in its dividend warrant not only the net amount actually paid, but the gross amount corresponding to that, and the rate and amount of income tax appropriate to that gross amount. Finance Act, 1924, 14 \& 15 Geo. V, c. 21, §33; Rhokana Corporation v. Commissioners of Inland Revenue, [1938] A. C. 380.

54. Finance Act, 1931, 21 \& 22 GEo. V, c. 10, \$7; Hamilton v. Commissioners of Inland Revenue, [1931] 2 K. B. 495. A corporation has a right to deduct tax in paying a dividend out of the excess of the rents over the annual values under Schedule $A$, aithough the amount of tax paid by the corporation is measured by the annual values 
This departure from the pure withholding system may be justified on the ground of administrative expediency. When a corporation distributes an amount accumulated over the years, it is difficult to allocate properly the various rates applicable to each portion of income. Taxes might possibly be collected from a corporation only when funds were disbursed. But this alternative would permit untaxed accumulations of wealth in corporations and thus discourage distribution. ${ }^{55}$

The treatment of amounts withheld in computing surtax rates constitutes a further departure from the pure withholding principle. Under the surtax provisions amounts withheld for taxes by the corporation are considered to lee income in arriving at the total income of the individual against which surtax is charged. ${ }^{56}$ If this process of "grossing up" were not followed, discrimination would result; for an individual receiving income through dividend disbursements would be accorded a reduction in his income base subject to surtax, while a person receiving his income from non-corporate enterprise would have to pay a surtax on his entire income above the point where the surtax becomes effective. In addition, even though a corporation does nut exercise its right of withholding and distributes a dividend "free of tax," it is deemed to have exercised that right for the purposes of the surtax as applied to the income of the individual receiving the dividend. When a dividend is distributed "free of tax," Section 33 of the Finance Act of 1924 requires that the dividend warrant declare the amount which would have been withheld plus the amount actually distributed as the full worth of the dividend. Thus if the amount distributed "free of tax" by a corporation is $\$ 100$ and the amount that ordinarily would be withleld is 654 , the dividend warrant must declare the distribution as being a gross dividend of $£ 154$ less tax of $£ 54$, anil the recipient must pay a surtax on the $\$ 154$.

Some corporations attempted to avoid the effect of this section by declaring that their dividends were distributed "without deduction of tax." It was hoped that the recipients of dividends would have to pay surtax only on amounts actually received. A corporation could avoid the possibility of the full standard rate's then being collected from both itself and the individual on the same income by reducing the dividend it declared to the extent of tax it had

and not by the rents and the corporation is not liable under Schedule $D$ to pay taxi on the excess. Neumann v. Commissioners of Inland Revenue, [1933] 1 K. B. 728; Fry v. Salisbury House Estate, [1930] A. C. 432.

55. Another alternative would be to treat the relationship between the corpuration and its shareholders as if a partnership. Theoretically profits wuuld then to split among all the shareholders for the purposes of income taxation, and a tax would never be levied on the corporation in its individual capacity.

56. Finance Act, 1927, $17 \& 18$ GEo. V, c 10, $\$ 39(2)$; Finance Act, 1931, 21 \& 22 GEo. V, c $28, \$ 7(2)$. For provisions dealing with "grossing up" on dividends un preferred stock as opposed to regular, varying dividends, see Finance Act, 1930, 20 \& 21 GEo. V, c. $28, \S \S 12(3)$; Finance Act, $1940,3 \&$ \& GEo. VI, c. $29, \S 20$ (1) (b). 
paid. ${ }^{57}$ At first the courts permitted the use of this clevice only in certain situations; namely, when all the surplus funds of the corporation were distributed in this manner ${ }^{58}$ or when a total, specially segregated amount of income was disbursed without deduction of tax. ${ }^{50}$ Later the House of Lords, in Cull v. Commissioners of Inland Revenue, ${ }^{60}$ sustained the general proposition that there can be no "grossing up" of income for surtax computation when tax is not "in fact deducted" on the dividend distribution. In this case the court adopted a position consistent with the withholding principle, since an amount actually not withheld could not be treated as such. The legislature, in $1940,{ }^{61}$ however, precluded a possible reduction of the base sulject to the surtax ${ }^{62}$ by stating that a dividend paid "without deduction of tax" should be deemed a net amount and subject to "grossing up." Although the application of "grossing up" to dividend payments nominally without deduction may be viewed as a departure from the pure withholding concept, it is in reality a recognition of the fact that the corporation practices withholding in diminishing its dividends by the amount of the tax it pays. If this is a departure from the withholding system, it may be explained as a modification in the interest of administrative simplicity and the equitable operation of the meclanism.

Although for many years widely employed in the British tax system, the withholding principle was not applied to the taxation of wages until the pressures of wartime taxation necessitated its use. Some provision had to be made to help the low income groups to meet their increased tax burden. In 1940 the tax on a couple, with two children, earning $£ 500$ a year was four times as great as in 1939, and for a similarly situated couple earning $f 800$ it was twice as great. Moreover, the number of wage earners liable for tax increased from less than one million in 1937-38 to five and a half million in 1941-42.03

In the application of withholding to taxes on all wages, a method of assessment which had previously been used only in the taxation of weekly mantal wage earners was adopted. ${ }^{64}$ Under this method manual wage earners were

57. The fact that a corporation can reduce its dividends by the amount of tax it has paid suggests the possibility that there is, actually, no withholding at all involved in dividend distribution. It might be contended that instead of withholding there is merely a smaller fund available for distribution and that the tax that is imposed is simply a tax on the corporation. The discrepancies between the tax on the corporation and the amount deducted from the dividend would tend to support this analysis. But if it were valid any explanation as to why the surtax is calculated as if there were withholding would necessarily be strained. It would also be difficult to explain the refund granted when the tax liability is at the $371 / 2 \%$ rate and the rate assessed on the corporation is $50 \%$.

58. See Neumann v. Commissioners of Inland Revenue, [1933] 1 K. B. 728.

59. Commissioners of Inland Revenue v. Pearson, [1936] 2 K. B. 533.

60. [1940] A. C. 51. The House of Lords overruled Commissioners of Inland Revenue v. Pearson, [1936] 2 K. B. 533.

61. Finance Act No. 1, 1940, 3 \& 4 GEo. VI, c. 29, \$20(1); sec also id. at $\$ 20(3)$.

62. See [1940] Scors L. T. 21.

63. See The Taxatton of Weekly Wage Earners, 1942, Cmd. 6348, 4.

64. Income Tax Act, 1918, 8 \& 9 Geo. V, c. 40, \$2; Finance Act, 1925, 15 \& 16 Geo. $V$, c. $36, \S 18$. A weekly wage earner was defined as "a person who receives wages which 
taxed on a half-yearly basis, ${ }^{65}$ and charged on their incomes for the preceding half-year ${ }^{66}$ rather than the preceding year. ${ }^{67}$ In merging witholding ${ }^{65}$ with this system of assessment, the tax liability created in one half-year period is paid through withholding by deductions from wages during the second halfyear period. Tax due by virtue of income in the first period, April 6 to October $5,{ }^{69}$ is deducted in equal weekly installments between the following February 1 and July $31 ; 0$ and the payment of tax due from the second period, October 6 to April 5,71 starts on August 1 and ends January 31.: Half of the regular allowances are taken against the assessments for the first period, and the other half against the assessments for the second period. ${ }^{73}$ The total tax owed by the employee for both half-years depends on his total income for the whole year. ${ }^{7 t}$

If the wage earner's income in the first period indicates that his income for the entire year will be above the taxable level, and yet his income for the second period is so small that his income for the year is below that level, any tax deducted from his earnings between February and July is repaid. ${ }^{70}$ Because wages in many industries fluctuate irregularly, a person whose yearly income is high enough to be taxed, may at times earn so little that deduction of tax from his wages would bring them below a subsistence level. The regulations, therefore, set limits below which tax may not be deducted, and this

are calculated by reference to the hour, day, week or any other periad less than a month, at whatever intervals the wages may be paid, or who receives wages, however calculated, which are paid daily, weekly, or at lesser intervals than a month." Income Tax Act, 1918, supra at $\$ 237$.

65. This result is brought about by Rule 2, Rules applicable to Cases I and II of Schedule D of the Income Tax Act of 1918, as amended by Finance Act, 1925, 15 \& 16 Geo. V, c. 36, 18 , made applicable to Schedule E, by Finance Act, 1922, 12 \& 13 Geo. V, c. 17, §18(2). See also S. R. \& O. 1925, No. 702, Reg. 29.

66. Under the half-yearly assessment, the assessment periods ran from April 6 to October 5, payment being made on January 1, and from Octoler 6 to .1pril 5, with p3yment on July 1. S. R. \& O. 1925, No. 702, Reg. 1 \& 12 .

67. Assessment on a yearly basis ran from April 6 to the succeeding April 5, with the time for payment set at January 1. Income Tax Act, 1918, 8 \& 9 GEo. V, c. 40.

68. The Commissioners of Inland Revenue were authorizcd, in 1940, to malse regulations which would merge withholding with the then existing system. Finance Act No. 2, 1940, 3 \& 4 Geo. VI, c. 4S, \$11(1), and S. R. \& O. 1940, No. 1776.

69. S. R. \& O. 1925, No. 702, Reg. 1 .

70. S. R. \& O. 1940, No. 1776, Reg. 6(2) as amended by S. R \& 0. 1942, No. 1324. See 379 H. C. DEB. (5th ser. 1942) 121.

71. S. R. \& O. 1925, No. 702, Reg. 1.

72. S. R. \& O. 1940, No. 1776, Reg. 6(2), as amended by S. R. \& 0.1942 , No. 1324. See $379 \mathrm{H}$. C. DEB. (5th ser. 1942) 121. Ordinarily, however, actual withholding terminates fifteen days before the end of each deduction period. S. R. \& O. 1940, No. 1776, Reg. 5(1).

73. S. R. \& O. 1925, No. 702, Reg. 4. Regulation 5 provides for a repayment if the correct amount has not been wholly allowed in the half-yearly assessment. Id., Reg. 5 .

74. See Mustoe, Incone Tax on Wage Eamers (1942) 92 L. J. 213, 214.

75. See The Taxation of Weekry Wage Earkers, op. cit. sispra note 63 , at 2. 
limit varies according to the family status of the individual. ${ }^{76}$ It is the wage earner's responsibility to invoke the limit to which he is entitled because of this status, and he may allow the full deduction to continue without restriction. ${ }^{77}$ If because of these limits or the employee's absence, the full amount of tax to be deducted from the week's wages is not deducted, subsequent weekly installments are not increased, but deductions are made, subject to the same limits, during a fifteen-day period before the end of the deduction period. ${ }^{78}$ Any tax which still remains undeducted is deducted during the second deduction period. ${ }^{70}$

Since the amount to be withheld is calculated by the Inland Revenuc Commission ${ }^{80}$ rather than by the wage earner or employer, a tremendous administrative problem is created. Although the assessment periods have always run from April 6 to October 5 and from October 6 to April 5, the withholding periods originally extended from January to June and from July to December. ${ }^{81}$ The enormity of the Commission's task when these withholding periods were in effect is indicated by the duties which it had to perform between October 5, the end of an assessment period, and January 1; and again between April and July. During these relatively short periods it had to obtain from employers returns of wages paid; ${ }^{82}$ and from employees, returns showing income from all sources and allowances claimed. ${ }^{83}$ It had to examine these returns and clear up all questions. Then on the basis of them it had to make assessments, taking into account wages, other income and specific reliefs. Finally, the Commission had to issue notices of assessment to workers, ${ }^{84}$ deal with appeals, make adjustments, ${ }^{85}$ and notify employers of the tax to

76. S. R. \& O. 1940, No. 1776, Reg. 7, as amended by S. R. \& O. 1942, No. 1324. Until recently these limits were $£ 1,17 \mathrm{~s}, 6 \mathrm{~d}$. for a single person and $£ 2,17 \mathrm{~s}, 6 \mathrm{~d}$. for a married person. S. R. \& O. 1940, No. 1776, Reg. 7, as amended by S. R. \& O. 1941, No. 1378.

77. S. R. \& O. 1940, No. 1776, Reg. 7(1), as amended by S. R. \& O. 1942, No. 1324.

78. S. R. \& O. 1940, No. 1776 , Reg. 5(1). See note 72 supra.

79. Id., Reg. 3(2). See The Taxation of WeEkly Wage Earners, loc. cit. supra note 63 .

80. See The Taxatton of Weekly Wage Earners, loc. cit. supra note 63.

81. S. R. \& O. 1925 , No. 702, Reg. 13.

82. S. R. \& O. 1940, No. 1776, Regs. 10, 10A, 14, and 16. See also Finance Act Na. 2 , $1940, \S 11(2)$. Other information, required of the employer, is the amount of tax he was required to deduct during the previous deduction period, the total amount deducted, and the amounts, if any, which he has been unable to deduct, together with the reason for the non-deduction. Ibid.

83. See The Taxation of Weekry Wage Earners, loc. cit. supra note 63. But it has now been decided that wage earner's returns need no longer include a statement of the wages; the employer's return is relied on for this information. But other income, apart from wages, must be included in the wage earner's return. Moreover, a wcekly wage earner need no longer fill out the regular return, but a greatly simplified form. Scc Mustoe, supra note 74, at 213, 214.

84. S. R. \& O. 1940 , No. 1776, Reg. 3(4).

85. If the wage earner objects to any assessment, he must give notice to the Inspector of Taxes stating the grounds of his objection. This notice must be given within 
be withheld $;^{86}$ for no tax is withheld until after the taxpayer has had an opportunity to claim the allowances due him, has been notified of the amount to be withheld and has exercised or waived his right of appeal. Every month the employer pays the tax withheld to the Collectur of Taxes, ${ }^{87}$ becoming in effect a collector of taxes charged with collection by installnents over a sismonths period. At the end of the period he must render an account on the form on which he was notified of the tax to be withleld. Yet failure by the employer to withhold any amount which he is charged to withhold does not discharge the employee from liability. 88

The period for handling returns, calculating the withlolding liahility, and supervising employer collection was so short that delay in the administration of the system was inevitable. Nevertheless, during the deduction period beginning in January, 1942, deduction began before the end of January in 90 per cent of the cases. ${ }^{89}$ But the problem still remained serious, for when deductions begin late the amount to be deducted from each payclieck in order to meet the liability within the particular deduction period must be increased. ${ }^{80}$

To obviate this administrative problem and avoid the hardships of delay it was proposed that a flat tax rate be applied to weekly wages."1 Thus the amount withheld would be ascertained by reference to the current weekly

21 days after the service of the notice of assessment. On receiving this notice of objection the Inspector can amend the assessment if he is satisfied with the validity of the objection, and then serve a notice of the amended assessment on the wage earner. If the Inspector is unable to agree as to the correct amount of the assessment, he must give notice to the clerk to the General Commissioner, and this notice operates as a notice of appeal by the wage earner. Alternatively, the wage earner can elect that his appeal should go to the Special Commissioners and in this event the Inspector of Taxes must give notice to their clerk. Notice must be given at least 14 days before the date fixed for the hearing of the appeal to the appellant and to the Inspector. If there is no appeal, the tax is payable on the same relevant dates or 21 days after service of the notice of assessment, whichever is later. If an appeal is successful and the assessment amended, the tas due is payable on the same relevant dates or within 14 days after issue of the notice of the amended assessment, whichever is later. S. R. \& O. 1925, No. 702, Regs. 8, 9, 10, and 11 ; S. R. \& O. 1940, No. 1776, Regs. 8, 9.

S6. S. R. \& O. 1940 , No. 1776, Regs. 3, 4. The notice specifies the name of the employee, the amount of tax which the employer is required to deduct, and the period during which the tax is to be deducted. But it does not disclose any particulars whatever, except for the above, regarding the income of the employee, or the reliefs from income tax to which he is entitled, or the year for which and the source of the emoluments in respect of which the tax is charged.

87. Id., Reg. 11. Regulation 11(3) provides: "Any amount of tax which an employer is required to pay to the Collector under this Regulation shall be a debt due to the Crown ... which ... . shall ... be recoverable in the same manner as if it had been declared by the Act of Parliament to be recoverable summarily as a civil debt." See, further, id., Reg. 21.

88. S. R. \& O. 1940, No. 1776, Regs. 17, 18. See also id., Regs. 12, 11, 13, 10, and $10 \mathrm{~A}$.

89. See The Taxation of WeEriy Wage Earners, loc. cit. supro note 63.

90. See 379 H. C. Deb. (5th ser. 1942) 121.

91. See The Taxation of Weekry Wage Eariers, op. cit. sipro note 63 , at 5. 
earnings of the employee. Under this system detailed Inland Revente assessments would be eliminated and the problem of seasonal variations would be solved, for the amount withheld would fluctuate with the wage. Since the progressive surtax rate structure in the United Kingdom applies to only relitively high incomes, it is doubtful whether the rate applied to wages under this proposal would have to be adjusted to prevent overwithholding. There wotild be some problem of adjustment in the very low income groups, however, in view of the possibility of applying a specially reduced rate now provided instead of the flat standard rate. In addition the tax would have to provide for a weekly minimum subsistence wage below which no tax could be deducted. This wage would be ascertained by reference to family allowances and the amounts exempt from tax. Moreover, the earned income allowance and certain credits, such as the one granted to people over 65 , which depend on total income, would have to be taken into account. All of these factors woutd not only determine the basic minimum but would be relevant in forestalling the possibility of refunds. ${ }^{22}$

Because of the difficulties inherent in the proposal the Inland Revenue decided to continue the half-yearly assessment plan. It was hoped that the delay previously experienced was only a temporary circumstance. The withholding period was, however, pushed back a month to allow additional time for adjustment. ${ }^{03}$ Thus, as we have seen, the withholding periods previously beginning in January and July, now begin in February and August.

In order to meet the problem created by variations in income earned by seasonal workers, the periods of assessment for them were altered to permit a more equitable allocation of income for the purposes of taxation. Thus wages earned by seasonal workers during the five months from April 6 to September 5 are now assessed as the income of the first half-year, and the full half-year allowances are permitted to be taken against the resulting total. Wages in the seven months from September 6 to April 5, the slack period, are assessed as the income of the second half-year, with the full half-yearly allowances granted. ${ }^{94}$ Accordingly, when wages are low the worker pays taxes on only five months of high earnings, and when his wages are high he pays taxes based on seven months of low earnings. The system may be altered for industries having different slack seasons or to alleviate cases of tudue hardship to workers in seasonal industries unaffected by the seasonal variation.

Although the original system as adjusted by the postponed period of collection and the provision for seasonal workers has met with general approval,

92. Another system was advanced which involved approximate weekly deductions varying according to scales worked out for rough classes; a taxpayer with one child being charged under one scale, and a taxpayer having two children being charged under another. Id. at 10.

93. See 379 H. C. DEB. (5th ser. 1942) 121. See notes $69-72$ supra, and accompany. ing text.

94. S. R. \& O. 1942, No. 1970, under Finance Act, 1942, 5 \& 6 Gko. VI, c. 2I, $\S 24(1)$. 
the scheme does not entirely fulfill the requirements of wartime taxation. Payments are now based on income received in the preceding half-year. If purchasing power increases are to be expeditiously checked, they should, however, be based more nearly on current income. Mforeover, because of the possibility of delay, payments under the present system may not be completely spread out over the year.

These difficulties could be mitigated in some measure by modifying the present plan to provide for tentative tax payments based on an individual's income for the preceding half-year, with adjustments for discrepancies between income received in the current and preceding period. Withlolding would legin at the start of the year before the Inland Revenue had completed its computation of assessment and would be on an approximate basis for six wecks. Ifter six weeks the Inland Revenue would have finished its assessment cumputation based on the preceding period's income. The amount already withheld on an approximate basis would then be subtracted from the amount calculated, and the remainder would be withheld in equal amounts during the weeks left in the current assessment period. At the end of that period actual incume received would be computed and additional charges made against the taxpayer or a refund granted for overcollection.

If the additional charge were paid at the end of the current assessment period, the tax obligation would be fulfilled more currently than under the present system. When there is relatively little variation in income from year to year, a calculation based on the preceding year's income would not involve too burdensome an adjustment. Should this advantage prove too inconsequential, the tentative character of the scheme could be dropped and the tax paid on the preceding half-year's income. But witholding for a period of six weeks at an assumed rate would mitigate any difficulty caused by the deky between assessment periods and could be retained in any event.

\section{Forced Savings}

In addition to providing a method of collection which eases the tax burden on the low income groups, the British have also provided for the return, after cessation of hostilities, of part of the tax collected. The plan finally adopted was inspired by a system of forced savings advocated early in the war by John Maynard Keynes. ${ }^{95}$ Under the Keynes plan, a progressively increasing percentage of all income in excess of a stipulated amount was to be paid to the government, partly through compulsory saving and partly through direct taxation. Part of this amount was to be credited as a deposit in the Post Office Savings Bank; the balance, to discharge the taxpayer's income tax liahility. The amount deposited was not to be used by the individual fur current expenditures or as security for loans. Yet it could be withdrawn to meet pre-war commitments of a capital nature, or exceptional and unavoidable

95. See Keynes, How to Pay for the Was (1940). 
expenses. Deposits were to be returned after the war to create purchasing power to take up the slack caused by the cessation of government spending on a vast scale. But to avoid the possibility of inflation they were to be returned in a series of installments.

A system of forced savings was not adopted immediately at the beginning of the war. In 1941, however, the Chancellor of the Exchequer recognized an inflationary gap of $£ 500$ million, only one-half of which, according to his estimates, could be met by an increased, intensified voluntary savings program. The possibility of an individual excess-profits tax was considered, but rejected because the tax would reach earned income only, investment income decreasing in wartime, and thus yield too little reventue. Moreover, it would be difficult to establish an equitable standard for measuring individual excess profits. $^{\text {.6 }}$ Another suggestion, that there be a tax on services, was also rejected since it would not provide for sufficient revenue. ${ }^{07}$

Unlike the Keynes plan, which would have operated for the most part outsicle the regular tax structure, the method ultimately adopted operated as an adjunct to the regular system. Under this plan, tax increases caused by reductions of personal and earned income allowances were credited to the taxpayer's account for post-war distribution. The earned income allowance was reduced from an amount representing one-sixth of earned income, subject to a maximum allowance of $£ 250$, to an amount representing one-tenth of this income and a maximum of $£ 150$. The existing personal allowances were reduced from $£ 170$ for a married taxpayer and $£ 100$ for a single taxpayer to $£ 140$ and $£ 80$, respectively. The exemption limit was reduced from $£ 120$ to $£ 110 .^{98}$ This decrease in allowance mainly affected persons with low incomes and increased by $2,000,000^{99}$ the number of taxpaying weekly wage earners. The post-war credit granted is in the form of a Post Office Savings Account in the name of the taxpayer, which is to be paid at a particular date, set by the Treasury, ${ }^{100}$ some time after the end of hostilities. Because of the clerical work involved, no Post Office Savings Books have been issued for these cred-

96. See $370 \mathrm{H}$. C. DEB. (5th ser. 1941) 1327. The proposals would involve the imposition of a percentage charge on all excesses of earned income (about $20 \%$ ) over earnings assessed from a standard year with a minimum standard of $t 150$. In addition to its failing as an adequate source of revenue, the individual excess-profits tax would take away just reward for increased labor from the wage earner.

97. Id. at 1329.

98. Finance Act, $1941,4 \& 5$ Gro. VI, c. 30, §6. The Act also lowered the benefit granted by the reduced rate on income up to \pm 165 by making this rate .65 of the standard rate instead of .59 of the standard rate. The deduction of tax from earned income is granted on an amount of one-tenth of such income rather than one-sixth. Ibid.

99. See 370 H. C. Des. (5th ser. 1941) 1330.

100. Finance Act, 1941, 4 \& 5 GEo. VI, c. 30, $\$ 7(1)$. When a taxpaycr's wife has an independent income, any amount of post-war credit that would be granted to him only, may upon application be granted partly to him and partly to her in such proportion as may be agreed between them or in the absence of such agreement by certain alternative methods. Id., § 7(2). 
its, but plans are being made to issue certificates to all persons concerned showing the amount of the credit and its elements. ${ }^{101}$ Contrary to the belief of some commentators, none of this credit is going to be held after the war to neet income tax arrears. ${ }^{102}$ Yet credits are not assignable, although they may be collected by a personal representative in the taxpayer's name or transmitted as a debt due from the Crown upon the death of the taxpayer. ${ }^{103}$

"Forced lending," like other provisions in the tax system, is predicated upon a progressive rate structure. The following table will indicate the degree to which post-war savings effect various levels of income:

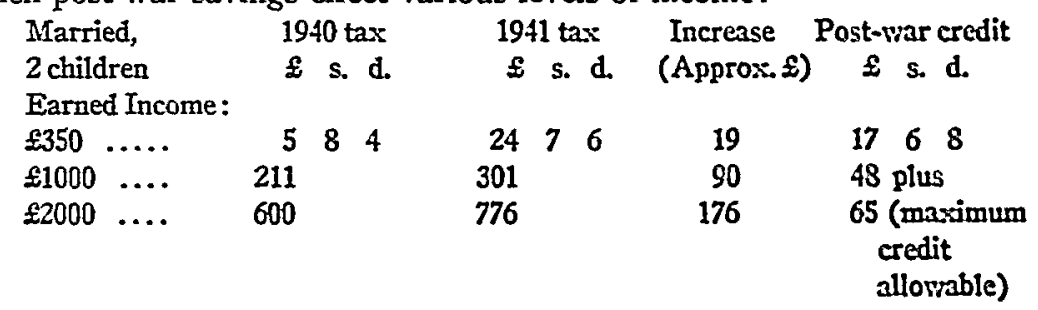

It is clear, therefore, that the increase in post-war credit is not proportionate to the increase in tax liability.

The present scheme, like the Keynes plan, will increase purchasing power after the war. During the first year of its operation, $£ 60,000,000$ out of a total of $£ 125,000,000$ received from weekly wage earners was designated to be returned in the form of post-war credits after the war. ${ }^{108}$ At this rate, if the war continues for a few more fiscal years, credits will be large enough to aid Great Britain in overcoming a possible post-war depression. Thus the Keynes plan was adopted in Great Britain in a form sufficiently in keeping with the regular tax structure to insure efficient collection. At the end of the first year, the plan lived up to the government's expectations, and in spite of the operation of the scheme, voluntary savings did not suffer, but actually increased. ${ }^{105}$

Despite formal procedural differences there is in the concept of taxable income a basic similarity between the British and United States systems of taxation. Nevertheless treatment of capital gains differs substantially in the two countries; but, contrary to popular belief, the British treatment is, because of its uncertainties, no more conducive to a stable economy than our own. British experience with withholding at the source may, however, prove valuable in the broader application of this method of collection to the United States tax structure. And the British use of forced savings suggests a vay of reducing the present wartime inflationary gap and meeting a possible post-war depression created by a deficiency in consumer purchasing power.

101. See 379 H. C. DEB. (5th ser. 1942) 123.

102. Id. at 124.

103. Finance Act, 1941, 4 \& 5 GEo. VI, c. 30, §7(4).

104. See 379 H. C. DEB. (5th ser. 1942) 124.

105. Id. at 112 . 